\title{
Density functional theory studies on the structure, vibrational spectra of three new tetrahalogenoferrate (III) complexes
}

\author{
Shahriare Ghammamy ${ }^{1,2^{*}}$, Kheyrollah Mehrani ${ }^{1}$, Somayyeh Rostamzadehmansor ${ }^{1}$, \\ Hajar Sahebalzamani ${ }^{1}$ \\ ${ }^{1}$ Departments of Chemistry, Faculty of Science, Ardabil Branch, Islamic Azad University, Ardabil, Iran;
*Corresponding Author: shghamami@yahoo.com
${ }^{2}$ Department of Chemistry, Faculty of Science, Imam Khomeini International University,Ghazvin, Iran.
}

Received 9 January 2011; revised 2 March 2011; accepted 12 March 2011.

\begin{abstract}
Three new tetrahalogenoferrate (III) complexes with the general formula $(\mathrm{R})_{4} \mathrm{~N}\left[\mathrm{FeCl}_{3} \mathrm{X}\right]^{-}$in that $\left(\mathrm{X}=\mathrm{F}^{-}, \mathrm{Cl}^{-}, \mathrm{Br}^{-}\right)$synthesized by the reaction of $\mathrm{FeCl}_{3}$ with $\left(\mathrm{C}_{2} \mathrm{H}_{5}\right)_{4} \mathrm{NF},\left(\mathrm{CH}_{3}\right)_{4} \mathrm{NCl}$ and $\left(\mathrm{C}_{4} \mathrm{H}_{9}\right)_{4} \mathrm{NBr}$ salts in anhydrous $\mathrm{CH}_{3} \mathrm{CN}$. These were characterized by elemental analysis, IR, UV/Visible and ${ }^{81} \mathrm{Br}-\mathrm{NMR}$ spectroscopy. The optimized geometries and frequencies of the stationary point are calculated at the B3LYP/LANL2DZ level of theory. Harmonic vibrational frequencies and infrared intensities for $\mathrm{FeCl}_{3} \mathrm{~F}^{-}, \mathrm{FeCl}_{4}^{-}$and $\mathrm{FeCl}_{3} \mathrm{Br}^{-}$are studied by means of theoretical and experimental methods. The calculated frequencies are in reasonable agreement with the experiment values.
\end{abstract}

Keywords: Tetrahalogenoferrate(III); Theoretical Study; Br-NMR; Density Functional Calculations

\section{INTRODUCTION}

Recently, the interesting history and development of the chemistry of iron halides was reviewed [1]. A new interest steeply increasing in the last decade is caused by possibility of ferrate use as a strong oxidizing agent for environmental uses [2-5] and as a high capacity source of cathodic charge [6-8]. Furthermore it was found that some iron (III) complexes provide a useful structural and electronic model for the similarly coordinated iron (III) sites found in the heme iron enzymes [9]. The tetrahalogenoferrates (III) have been utilized in bioinorganic chemistry as reagents for synthesizing some model compounds, such as $\left[\mathrm{Fe}_{2} \mathrm{~S}_{2} \mathrm{Cl}_{4}\right]^{2-}[10,11]$. The investiga- tion of the structures and properties of these compounds and their similarities are interested. In this work, we report on the synthesis and characterisation of new complexes of type $(\mathrm{R})_{4} \mathrm{~N}\left[\mathrm{FeCl}_{3} \mathrm{X}\right]^{-}\left(\mathrm{X}=\mathrm{F}^{-}, \mathrm{Cl}^{-}, \mathrm{Br}^{-}\right) \mathrm{Ob}-$ tained directly from $\mathrm{FeCl}_{3}$ and tetraalkylammonium salts. During this study we report the optimized geometries and infrared spectral measurements, assignments and electronic structure calculations for compounds. The structures of compounds have been optimized by the density functional theory (DFT) based method at B3LYP/ LANL2DZ levels of theory, using the Gaussian 03 package of programs [12-14]. The comparison between theory and experiment is made.

\section{EXPERIMENTAL SECTION}

\subsection{General}

The density functional and abinitio calculation have been performed with the Gaussian program and the basis sets implemented therein [13,15-17].

Acetonitrile (Fluka, P.A.) was distilled several times from phosphorus pentaoxide before use, thereby reducing its water content to $<4 \mathrm{ppm}$. $\mathrm{FeCl}_{3}$ (Merck, p.a.) were used without further purification. Anhydrous $\mathrm{Et}_{4} \mathrm{~N}^{+} \mathrm{F}^{-}$and $\mathrm{Me}_{4} \mathrm{~N}^{+} \mathrm{F}$ were obtained by a drying procedure of the tetrahydrate in high vacuum $\left(\mathrm{d}, 130^{\circ} \mathrm{C}\right)$ [18]. Infrared spectra were recorded as $\mathrm{KBr}$ disks on a Shimadzu model 420 spectrophotometer. The UV/Visible measurements were made on an Uvicon model 922 spectrometer. ${ }^{81} \mathrm{Br}-\mathrm{NMR}$ were recorded on a Bruker AVA NCEDRX 500 spectrometer. The percent compositions of elements were obtained from the Microanalytical Laboratories, Department of Chemistry, OIRC, Tehran. 


\subsection{Synthesis of Tetraethylammonium Fluorotrichloroferrate (III), $\left[\left(\mathrm{C}_{2} \mathrm{H}_{5}\right)_{4} \mathrm{~N}\right]\left[\mathrm{FeCl}_{3} \mathrm{~F}\right](1)$}

To a solution of $\mathrm{FeCl}_{3}(0.26 \mathrm{~g}, 1.6 \mathrm{mmol})$ in $\mathrm{MeCN}$ the solid powder tetraethtylammonium fluoride $(0.26 \mathrm{~g}$, $1.74 \mathrm{mmol}$ ) was added under stirring at room temperature until yellow solid precipitate was formed. After $2 \mathrm{~h}$ stirring, the mixture was filtered, washed ether, and dried at room temperature. m.p. $229-231^{\circ} \mathrm{C}$. Anal. Calc. for $\mathrm{C}_{8} \mathrm{H}_{20} \mathrm{NFeCl}_{3} \mathrm{~F}$ : C, 25.78; $\mathrm{H}, 5.37$; N, 3.76. Found: $\mathrm{C}$, 26.45; H, 5.89; N, 4.32\%. IR (KBr) $\left(\mathrm{cm}^{-1}\right): 3438,3225$, 3028, 2987, 2946, 2780, 2655, 2358, 1850, 1462, 1401, 1307, 1021, 792, 499, 483, 428. UV-Vis in $\mathrm{CH}_{3} \mathrm{CN}$, $\lambda / \mathrm{cm}^{-1}:$ 41493, 36496, 31847, 27548.

\subsection{Synthesis of Tetramethylammonium Tetrachloroferrate (III), $\left[\left(\mathrm{CH}_{3}\right)_{4} \mathrm{~N}\right]\left[\mathrm{FeCl}_{4}\right](2)$}

Solid powder tetrametylammonium chloride $(0.22 \mathrm{~g}, 2$ mmol) was added to a solution of $\mathrm{FeCl}_{3}(0.29 \mathrm{~g}, 1.78$ $\mathrm{mmol}$ ) in $\mathrm{MeCN}$ under stirring at room temperature until yellow solid precipitate was formed. Stirring was continued for $3 \mathrm{~h}$. the mixture was filtered, washed with ether, and dried at room temperature. m.p. $299-300^{\circ} \mathrm{C}$. Anal. Calc. for $\mathrm{C}_{4} \mathrm{H}_{12} \mathrm{NFeCl}_{4}$ : C, 17.65; H, 4.41; N, 5.15. Found: C, 17.96; H, 4.96; N, 5.52\%. IR ( $\mathrm{KBr})\left(\mathrm{cm}^{-1}\right)$ : $3421,3225,3017,2980,2960,2780,2655,2477,1850$, 1484, 1411, 1283, 948, 499, 416. UV-Vis in $\mathrm{CH}_{3} \mathrm{CN}$, $\lambda / \mathrm{cm}^{-1}:$ 41666, 36630, 31948, 27624.

\subsection{Synthesis of Tetrabuthylammonium Bromotrichloroferrate (III), $\left[\left(\mathrm{C}_{4} \mathrm{H}_{9}\right)_{4} \mathrm{~N}\right]\left[\mathrm{FeCl}{ }_{3} \mathrm{Br}\right](3)$}

To a solution of $\mathrm{FeCl}_{3}(0.167 \mathrm{~g}, 1.02 \mathrm{mmol})$ in $\mathrm{MeCN}$ the solid powder tetrabuthtylammonium bromide $(0.365$ $\mathrm{g}, 1.13 \mathrm{mmol}$ ) was added under stirring at room temperature until dark red solid precipitate was formed. After $2 \mathrm{~h}$ stirring, the mixture was filtered, washed ether, and dried at room temperature. m.p. $69-70^{\circ} \mathrm{C}$. Anal. Calc. for $\mathrm{C}_{16} \mathrm{H}_{36} \mathrm{NFeCl}_{3} \mathrm{Br}$ : C, 39.46; H, 7.43; N, 2.89 . Found: C, $40.01 ; \mathrm{H}, 8.21 ; \mathrm{N}, 3.59 \%$. IR( $\mathrm{KBr})\left(\mathrm{cm}^{-1}\right)$ : $3431,3315,3225,3010,2961,2875,2765,2398,1950$, 1466, 1382, 1169, 1042, 531, 463, 453. UV-Vis in $\mathrm{CH}_{3} \mathrm{CN}, \lambda / \mathrm{cm}^{-1}: 42016,36764,31645,27624$.

\subsection{Computational Methods}

Density functional theory (DFT) calculations were carried out at B3LYP/LANL2DZ levels of theory with the Gaussian 03 package of programs $[13,19]$ which combines the exact Hartree-Fock exchange with Becke's and uses the Lee-Yang-Parr correlation function in order to include the most important correlation effects. The structures of the molecules were completely optimized without any symmetry in all the levels. The optimized structural parameters were used in the vibrational frequency calculations at the HF and DFT levels to characterize all stationary points as minima [20]. Harmonic vibrational frequencies in $\mathrm{cm}^{-1}$ and infrared intensities (int) in Kilometer per mole of all compounds were performed at the same level on the respective fully optimized geometries. These compounds and their data are in accordance with recent works on the formation of four coordinate intermediates.

\section{RESULTS AND DISCUSSION}

The $\left(\mathrm{C}_{2} \mathrm{H}_{5}\right)_{4} \mathrm{~N}\left[\mathrm{FeCl}_{3} \mathrm{~F}\right]$ complex was obtained by the reaction of $\left(\mathrm{C}_{2} \mathrm{H}_{5}\right)_{4} \mathrm{NF}$ with $\mathrm{FeCl}_{3}$ in the acetonitrile solvent (reaction (1)). The reaction of $\mathrm{FeCl}_{3}$ with $\left(\mathrm{CH}_{3}\right)_{4} \mathrm{NCl}$ in acetonitrile solvent gave $\left(\mathrm{CH}_{3}\right)_{4} \mathrm{~N}\left[\mathrm{FeCl}_{4}\right]$ (reaction (2)). $\left(\mathrm{C}_{4} \mathrm{H}_{9}\right)_{4} \mathrm{~N}\left[\mathrm{FeCl}_{3} \mathrm{Br}\right]$ synthesized by the reaction of $\mathrm{FeCl}_{3}$ with $\left(\mathrm{C}_{4} \mathrm{H}_{9}\right)_{4} \mathrm{NBr}$ in acetonitrile (reaction (3)).

$$
\begin{aligned}
&\left(\mathrm{C}_{2} \mathrm{H}_{5}\right)_{4} \mathrm{NF}+\mathrm{FeCl}_{3} \rightarrow\left(\mathrm{C}_{2} \mathrm{H}_{5}\right)_{4} \mathrm{~N}\left[\mathrm{FeCl}_{3} \mathrm{~F}\right] \\
&\left(\mathrm{CH}_{3}\right)_{4} \mathrm{NCl}+\mathrm{FeCl}_{3} \rightarrow\left(\mathrm{CH}_{3}\right)_{4} \mathrm{~N}\left[\mathrm{FeCl}_{4}\right] \\
&\left(\mathrm{C}_{4} \mathrm{H}_{9}\right)_{4} \mathrm{NBr}+\mathrm{FeCl}_{3} \rightarrow\left(\mathrm{C}_{4} \mathrm{H}_{9}\right)_{4} \mathrm{~N}\left[\mathrm{FeCl}_{3} \mathrm{Br}\right]
\end{aligned}
$$

The structures of complexes 1, 2 and 3 are shown in Figure 1 Geometry optimization shows that symmetry for compounds 1 and 3 is $C_{3 V}$. Geometry optimization shows that symmetry for compound 2 is $\mathrm{D}_{4 \mathrm{~h}}$. Selected bond distances and angles are reported in Table 1. We

\begin{tabular}{|c|c|c|c|}
\hline & \multicolumn{3}{|c|}{ B3LYP/LANL2DZ } \\
\hline & {$\left[\mathrm{FeCl}_{3} \mathrm{~F}\right]^{-}$} & {$\left[\mathrm{FeCl}_{4}\right]^{-}$} & {$\left[\mathrm{FeCl}_{3} \mathrm{Br}\right]^{-}$} \\
\hline \multicolumn{4}{|c|}{ Bond lengths ( $\AA$ ) } \\
\hline $\mathrm{Fe} 1-\mathrm{Cl} 2$ & 2.298 & 2.289 & 2.286 \\
\hline $\mathrm{Fe} 1-\mathrm{Cl} 3$ & 2.298 & 2.289 & 2.287 \\
\hline $\mathrm{Fe} 1-\mathrm{Cl} 4$ & 2.298 & 2.289 & 2.286 \\
\hline $\mathrm{Fe} 1-\mathrm{X} 5$ & 1.817 & 2.289 & 2.458 \\
\hline \multicolumn{4}{|l|}{ Bond angles $\left({ }^{\circ}\right)$} \\
\hline $\mathrm{Cl} 2-\mathrm{Fe} 1-\mathrm{Cl} 3$ & 109.829 & 109.462 & 109.971 \\
\hline $\mathrm{C} 12-\mathrm{Fe} 1-\mathrm{Cl} 4$ & 109.755 & 109.437 & 109.809 \\
\hline $\mathrm{C} 12-\mathrm{Fe} 1-\mathrm{X} 5$ & 109.129 & 109.46 & 109.075 \\
\hline $\mathrm{Cl} 3-\mathrm{Fe} 1-\mathrm{Cl} 4$ & 109.831 & 109.474 & 109.971 \\
\hline $\mathrm{Cl} 3-\mathrm{Fe} 1-\mathrm{X} 5$ & 108.152 & 109.501 & 109.918 \\
\hline C14-Fe1-X5 & 109.125 & 109.493 & 109.072 \\
\hline
\end{tabular}

Table 1. Geometrical parameters optimized of compounds1-3, bond length $(\AA)$ and angle $\left({ }^{\circ}\right)$. 

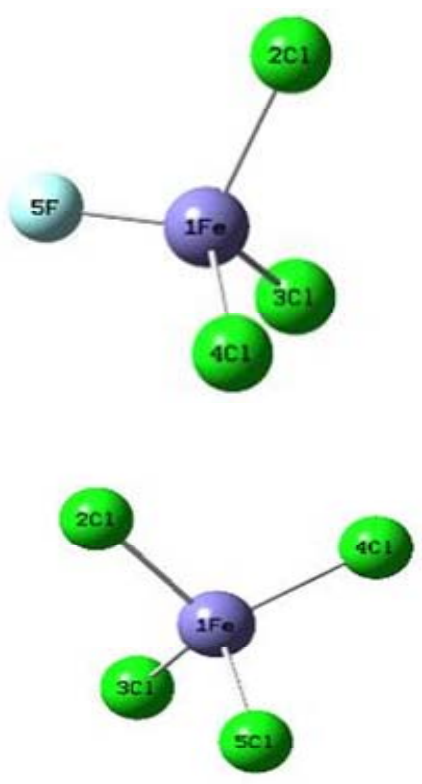

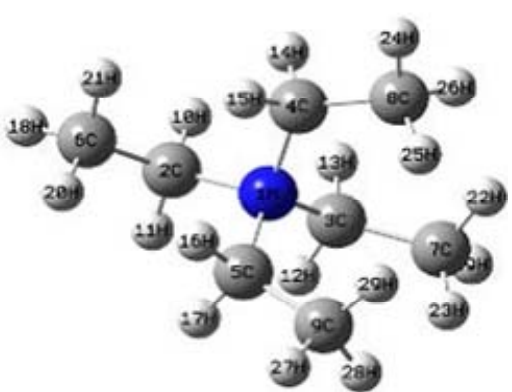

(a)

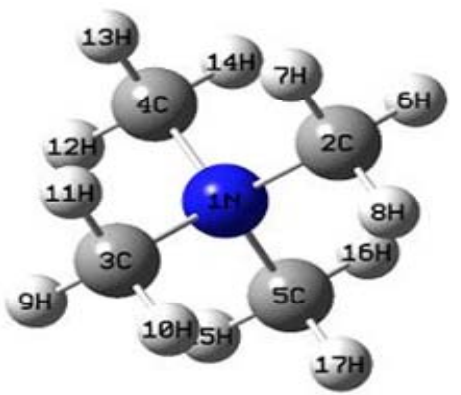

(b)
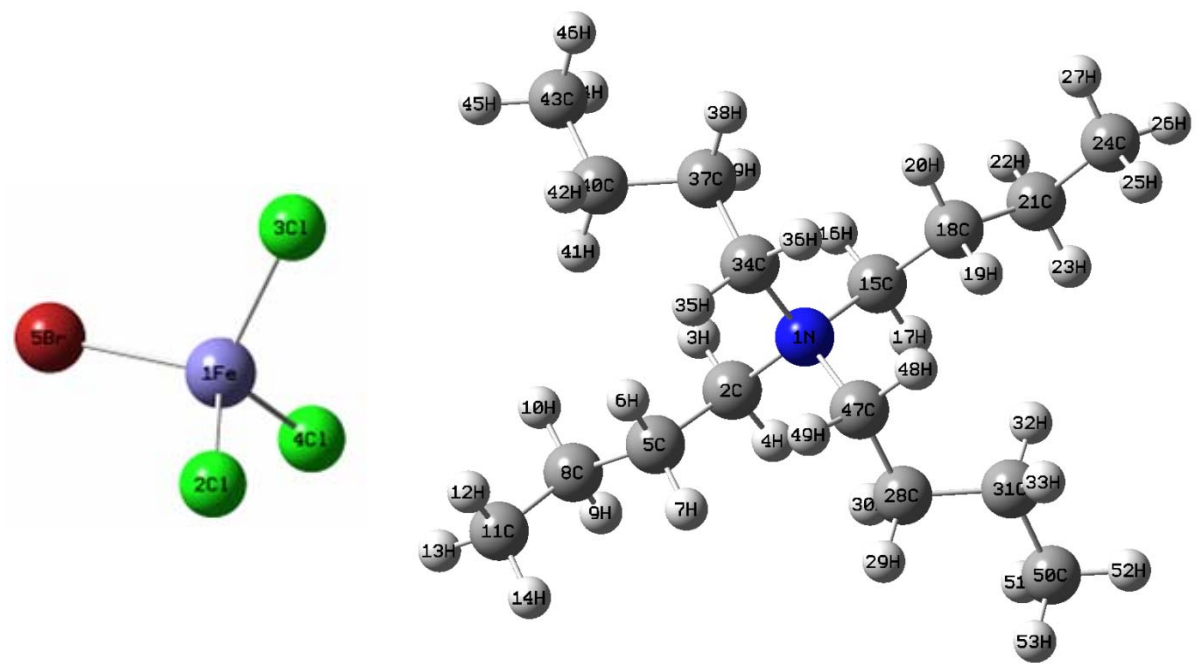

(c)

Figure 1. Optimized geometries of (a) $\left[\left(\mathrm{C}_{2} \mathrm{H}_{5}\right)_{4} \mathrm{~N}\right]\left[\mathrm{FeCl}_{3} \mathrm{~F}\right]^{-}$, (b) $\left[\left(\mathrm{CH}_{3}\right)_{4} \mathrm{~N}\right]\left[\mathrm{FeCl}_{4}\right]^{-}$, (c) $\left[\left(\mathrm{C}_{4} \mathrm{H}_{9}\right)_{4} \mathrm{~N}\right]\left[\mathrm{FeCl}_{3} \mathrm{Br}\right]^{-}$at B3LYP/LANL2DZ level of theory.

could not compare the calculation results given in Table 1 with the experimental data. Because the crystal structure of the title compound is not available till now. The calculations shown that the structures of these three trichlorohaloferrate salts, are not formed dimer, trimer, or more multi nuclear structures in solid states. B3LYP/ LANL2DZ results showed that the $\mathrm{Fe}-\mathrm{X}(\mathrm{X}=\mathrm{F}, \mathrm{Cl}, \mathrm{Br})$ bond length values for the $\left[\mathrm{FeCl}_{3} \mathrm{X}\right]^{-}$in compounds $1-3$ are $1.817,2.289$ and $2.458 \AA$, respectively. Also, the $\mathrm{Fe}-\mathrm{Cl}_{2}$ bond lengths values in $\left[\mathrm{FeCl}_{3} \mathrm{X}\right]^{-}$are 2.298, 2.2893 and $2.286 \AA$, respectively. These results reveal that the bond order for Fe-X bonds decrease from com- pounds 1 to 3 , while for $\mathrm{Fe}-\mathrm{Cl}_{2}$ bonds, the bond orders increase. It can be concluded that the decrease of Fe-X bonds lengths and the increase of $\mathrm{Fe}-\mathrm{Cl}_{2}$ bond lengths in compounds 1 - 3 result from the increase of the hyperconjugation from compounds 1 - 3 Besides, the $\theta_{\mathrm{Cl} 2-\mathrm{Fe} 1-\mathrm{X} 5}$ bond angle values in compounds 1 - 3 are 109.129, 109.46 and 109.075, respectively (see Table 1). The decrease of $\theta_{\mathrm{C} 12-\mathrm{Fe} 1-\mathrm{X} 5}$ bond angle values from compounds 1 to 3 , could again, be explained by the increase of the hyperconjugation from compounds 1 to 3 . The calculated infrared spectra of three ferrate complexes are presented in Figure 2. The solid-state IR spectrum for 
the complexes 1, 2 and 3 shows $\mathrm{Fe}-\mathrm{Cl}$ stretching resonances $\left(300-400 \mathrm{~cm}^{-1}\right)$. The harmonic vibrational frequencies of all the stationary points at the B3LYP/ LANL2DZ level along with the available experimental data [21-23] presented in Table 2. The compounds structure shows the presence of $\mathrm{Fe}-\mathrm{Cl}$ stretching vibrations in the region $350-400 \mathrm{~cm}^{-1}$ which is the characteristic region for the ready identification of the $\mathrm{Fe}-\mathrm{Cl}$ stretching vibrations. In general the compounds $\mathrm{Fe}-\mathrm{Cl}$ vibrations calculated theoretically are in good agreement with the experimentally reported values.

Zero-point energies (ZPE) and several calculated thermodynamic parameters of compounds $1-3$, are given in Table 3. The total energies of compounds $\left[\mathrm{FeCl}_{3} \mathrm{~F}\right]^{-}$, $\left[\mathrm{FeCl}_{4}\right]^{-}$and $\left[\mathrm{FeCl}_{3} \mathrm{Br}\right]^{-}$at 298 temperature at $\mathrm{B} 3 \mathrm{LYP} /$ LANL2DZ methods are also presented.
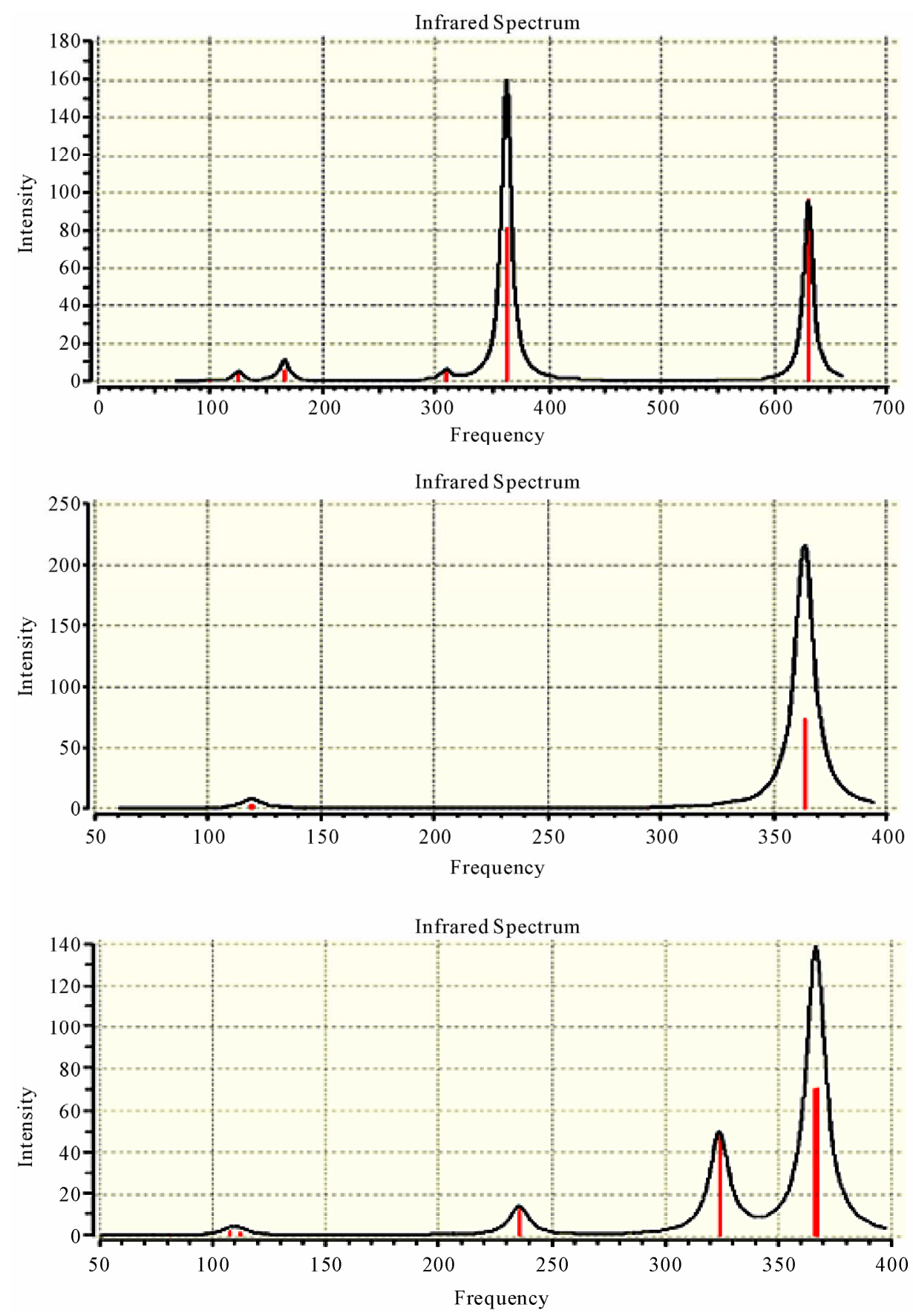

Figure 2. Calculated infrared spectra of $\mathrm{FeCl}_{3} \mathrm{~F}^{-}, \mathrm{FeCl}_{4}^{-}$and $\mathrm{FeCl}_{3} \mathrm{Br}^{-}$(top to bottom, frequencies in $\mathrm{cm}^{-1}$, intensities in arbitrary units). 
Table 2. Calculated and experimental frequencies of compounds $1-3\left(\mathrm{~cm}^{-1}\right)$.

\begin{tabular}{ccc}
\hline Compound & B3LYP/LANL2DZ & Exptl \\
\hline$\left[\mathrm{FeCl}_{3} \mathrm{~F}\right]^{-}$ & $125,165,309,362,630$ & 792,483 \\
{$\left[\mathrm{FeCl}_{4}\right]^{-}$} & 119,362 & 378 \\
{$\left[\mathrm{FeCl}_{3} \mathrm{Br}\right]^{-}$} & $110,235,325,362$ & 376 \\
\hline
\end{tabular}

Table 3. Theoretically computed energies, zero-point vibrational energies and Gibs free energy for compounds $1-3$.

\begin{tabular}{cccc}
\hline \multicolumn{4}{c}{ B3LYP/LANL2DZ } \\
\hline Parameters & {$\left[\mathrm{FeCl}_{3} \mathrm{~F}\right]^{-}$} & {$\left[\mathrm{FeCl}_{4}\right]^{-}$} & {$\left[\mathrm{FeCl}_{3} \mathrm{Br}\right]^{-}$} \\
HF energy & -268.437381 & -183.540346 & -181.756907 \\
Zero-point energy & 0.005080999 & 0.004219585 & 0.003912898 \\
Total energy & -268.4323003 & -183.536126 & -181.7529941 \\
Gibs Free energy & -268.468259 & -183.5732334 & -181.7912501 \\
\hline
\end{tabular}

\section{CONCLUSIONS}

Three tetraalkylammonium salts of $\mathrm{FeCl}_{3}$ were synthesized in one step and characterized by elemental analysis, IR, UV/Visible, and ${ }^{81} \mathrm{Br}-\mathrm{NMR}$ techniques. Production of these compounds show the ability of tetraalkylammonium salts in halide addition to transition metal and main group elements compounds and the optimized geometry parameters calculated at B3LYP/LANL2DZ level. The optimized structures are in good agreement with the available experimental results. In the present article, the infrared spectra of the ferrate halide complexes were studied using the theoretical and experimental methods. Our theoretical infrared spectrum of compounds $1-3$ are in very good agreement compared to our experimental spectrum.

\section{REFERENCES}

[1] Zubieta, J. and Mason, R. (1973) Iron-sulfur proteins: structural chemistry of their chromophores and related systems. General and Chemistry, 12, 390. doi:10.1002/anie.197303901

[2] Sharma, V.K. (2002) Potassium ferrate (VI): An environmentally friendly oxidant. Advances in Environmental Research, 6, 143-156. doi:10.1016/S1093-0191(01)00119-8

[3] Sharma, V.K., Winkelmann, K., Krasnova, Y., Lee, C. and Sohn, M. (2003) Heterogeneous photocatalytic reduction of ferrate (VI) in UV-irradiated titania suspensions: role in enhancing destruction of nitrgen-containing pollutants. Inernational Journal of Photoenergy, 5, 183190

[4] DeLuca, S.J., Chao, A.C., Smallwood, J.C. (1983) Ames test of ferrate treated water. Journal of Environmental Engineering, 109, 1159-1167.

doi:10.1061/(ASCE)0733-9372(1983)109:5(1159)

[5] Petira, O. (1985) Doctor of philosophy thesis, ICT, Prague.

[6] Licht, S., Wang, B. and Ghosh, S. (1999) Energetic Iron (VI) chemistry: the super-iron battery. Science, 285, 1039-1042. doi:10.1126/science.285.5430.1039

[7] Licht, S., Naschitz, V. and Wang, B. (2002) Rapid chemical synthesis of the barium ferrate super-iron Fe (VI) compound $\mathrm{BaFeO}_{4}$. Journal of Power Sources, 109, 67-70. doi:10.1016/S0378-7753(02)00041-1

[8] Licht, S., Tel-Vered, R. and Halperin, L. (2004) Towards efficient electrochemical synthesis of Fe (VI) ferrate, and super-iron battery compounds. Journal Electrochemical Society, 151, A31-A39. doi:10.1149/1.1630035

[9] Zhu, S., Brennessel, W.W., Harrison, R.G. and Que., L. (2002) Iron coordination chemistry of N-(bis(2-pyridyl) methyl)pyridine-2-carboxamide. Inorganic Chemistry Acta, 337, 32-38. doi:10.1016/S0020-1693(02)01032-0

[10] Smith, M.C., Ciao, Y., Wang, H., George, S.J., Coucouvanis, D., Koutmos, M., Sturhahn, W., Alp, E.A., Zhao, J. and Kramer, S.P. (2005) Normal-Mode Analysis of $\mathrm{FeCl}_{4}^{-}$and $\mathrm{Fe}_{2} \mathrm{~S}_{2} \mathrm{Cl}_{4}{ }^{2-}$ via Vibrational Mössbauer, Resonance Raman, and FT-IR Spectroscopies. Inorganic Chemistry, 44, 5562-5570. doi:10.1021/ic0482584

[11] Vrajmasu, V. V., Münck, E. and Bominaar, E. L. (2004) Theoretical analysis of the jahn-teller distortions in tetrathiolato iron (ii) complexes. Inorganic Chemistry, 43, 4862-4866. doi:10.1021/ic0400484

[12] Nori-Shargh, D., Roohi, F., Deyhimi, F. and Naeem-Abyaneh, R. (2006) DFT study and NBO analysis of the metallotropic shifts in cyclopentadienyl(trimethyl)silane germane and stannane. Journal of Molecular Structure: THEOCHEM, 763, 21-28. doi:10.1016/j.theochem.2006.01.011

[13] Frisch, M.J. and Trucks, G.W., et al. (1998) GASSIAN 98 (Revision A. 3) Gaussian Incumbent. Pittsburgh, PA, USA.

[14] He, H.Q., Liu, J.Y., Li, Z.S. and Sun, C.C. (2006) Theoretical study for the reaction of $\mathrm{C}_{2} \mathrm{H}_{5} \mathrm{Cl} / \mathrm{C}_{2} \mathrm{D}_{5} \mathrm{Cl}$ with $\mathrm{Cl}$ atom. Journal of Molecular Structure: THEOCHEM, 763, 59- 66. doi:10.1016/j.theochem.2005.12.038

[15] Hehre, W.J., Radom, L., Schleyer, P.V.R. and Pople, J.A., (1986) Ab initio molecular orbital theory, Wiley, New York.

[16] Lee, C., Yang, W., Parr, R.G. (1988) Development of the Colle-Salvetti correlation-energy formula into a functional of the electron density. Physical Reviews, 37, 785-789. doi:10.1103/PhysRevB.37.785

[17] Seminario, J.M. and Politzer, P. (1995) Modern density function theory, A tool for chemistry, Elsevier, Amsterdam.

[18] Christe, K.O., Wilson, W.W., Wilson, R.D., Bau, R. and Feng, J. (1990) Syntheses, properties, and structures of anhydrous tetramethylammonium fluoride and its 1:1 adduct with trans-3-amino-2-butenenitrile. Journal of American Chemical Society, 112, 7619-7625. doi:10.1021/ja00177a025

[19] Becke, A.D., (1993) Density functional theory of electronic structure. Journal of Chemical Physical, 98, 5648. doi:10.1063/1.464913 
[20] Sundaraganesan, N., Ilakiamani, S. and Dominic Joshua, B. (2007) Vibrational spectroscopy investigation using ab initio and density functional theory analysis on the structure of 3, 4-dimethylbenzaldehyde. Spectrochimica Acta Part A, 68, 680-687. doi:10.1016/i.saa.2006.12.046

[21] Nakamoto, K., (1978) Infrared and raman spectra of inorganic and coordiation compounds, 3rd Edition. John Wiley, New York.

[22] Wyrzykowski, D., Maniecki, T., Pattek-Janczyk, A., Sta- nek, J. and Warnke, Z. (2005) Thermal analysis and spectroscopic characteristics of tetrabutylammonium tetrachloroferrate(III). Thermochimica Acta, 435, 92-98. doi:10.1016/i.tca.2005.05.007

[23] Wyrzykowski, D., Pattek-Janczyk, A. and Maniecki, T., et al. (2006) Thermal analysis of quinolinium tetrachloroferrate (III). Thermochimica Acta, 443, 72-77. doi:10.1016/j.tca.2005.12.023 